in the short term can reduce the protein loss from the stomach. ${ }^{i-i}$ Various treatments that can lower hydrogen ion secretion by the gastric mucosa-long-term propantheline, vagotomy, ${ }^{6}$ and cimetidine ${ }^{*}$ - have also decreased protein loss, relieved symptoms, and, in the case of cimetidine and vagotomy, lead to mucosal improvement, though hyposecretion of acid is a prerequisite for making the diagnosis. The fibrinolysis inhibito tranexamic acid has been reported to relieve symptoms, reduce protein loss, and lead to mucosal recovery, ${ }^{9}$ although here also spontaneous recovery cannot be excluded.

What is clear from reports is that treatmen should be expectant, with therapeutic trials of the various agents that have been shown to be of value in some cases. Surgery should be reserved for certain definite indicationsnamely, prolonged intractable symptoms with severe hypoproteinaemic oedema, gastric bleeding, and neoplastic change. ${ }^{10}$

A patient under our care at Hammersmith Hospital indicated the value of expectant treatment. A 29-year-old woman presented with nausea, vomiting, epigastric pain, weight loss, and hypoproteinaemic oedema. She failed to show any definite improvement with anticholinergics and tranexamic acid. With encouragement and symptomatic treatment she improved over three months so that she was without symptoms and could return to work although her gastric mucosa was unchanged. We cannot be sure that surgery may not be necessary at some time, but at least she was spared a total gastrectomy at her initial presentation, when many would have been tempted to perform it.

B T COOPER

University Department of Medicine, Bristol Royal Infirmary, Bristol BS2 8HW

\section{S CHADWICK}

Department of Medicine,

Royal Postgraduate Medical School,

Hammersmith Hospital,
London W12 OHS

'Frank, B W, and Kern, F, Gastroenterology, 1967, 53, 953.

Berman, J R, and Spiegel, E L, Gastrointestinal Endoscopy, 1969, 15, 230

Jarnum, S, and Jensen, K B, Gut, 1972, 13, 128. Berenson, M M, Sannella, J, and Freston, J iw,

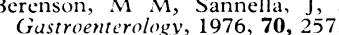
Gastroenterology, 1976, 70, 257.
91. I J, et al, Mayo Clinic Procedings, 1977, 52, Smith, R L,
$1978, \mathbf{7 4}, 903$.

1978, 74, 903. Krag, E, et al, Scandina
enterology, 1978, 13, 635.

Kondo, M, et al, Gastroenterology, 1976, 70, 1045.

, $\mathrm{GH}$, and Sleisenger, $\mathrm{M} \mathrm{H}$, Surgical Clinics of North America, 1962, 42, 1125.

\section{"The End of an Age of Optimism"}

SIR,-In his review of Professor Colin Dollery's 1978 Rock Carling Fellowship monograph Dr Tony Smith (27 January, p 255) repeatedly takes a side swipe at me. May I reply to his three main charges?

He states, firstly, that "neither Illich nor Bradshaw have [sic] really faced up to the paradox that their books are based on the writings of members of the profession under attack-doctors who were critical of medical care and were trying to improve it." I would now face it but, the motives of the doctor aside, which paradox is it that I am meant to face-from what other group would one expect any evidence to come? Only the expert sinne can confess his expert sins. Only doctors know the sins doctors commit; and to their modest credit a few doctors confess them, or at any rate reveal them-in medical journals. However, far more doctors reveal their sins unconsciously in their writings; and what doctors write has anyway always to be "trans lated" for the laity by such as Illich and myself. Lastly in this connection, and I say it in no carping spirit, the exact nature and gravity of the fundamental, though not absolutely identical, flaws Illich and I think we see in high-technology medicine-social and structural iatrogenesis in his case, and technoecological, cultural, and religious in minehave not been understood by the vast majority of doctors, including, I am sorry to have to say, Dr Smith (it is as though doctors have a blind spot of which they are quite unconscious). And still less has any doctor addressed himself to refuting the charge that those fundamenta flaws exist, or admitted to them.

Secondly, Dr Smith says that "Many of the defects and errors trumpeted by Bradshaw are now of only historical interest; for not only have they been corrected but so also has the system in which they occurred." (Is this the irregular verb "I hint, you state, he trumpets" ?) Yes, many faults have been eliminated but only to be replaced by as many more: doctors are as prolific of fresh errors as they are assiduous in the defence of their curren ones (and my catalogue is current as well as historical). Yes, the system has been corrected -and has then gone off course again in another direction. What is intrinsically wrong is not to be righted by extrinsic tinkerings.

Thirdly, Dr Smith states that "The Jeremiahs have been given excessive publicity; and their complaints have combined with unrealistic expectations . . . to persuade many non-medical intellectuals that high technology medicine has failed. In fact it has succeeded. " (And those non-medical intellectuals had best take a quick course of Coué-from the doctors, naturally.) Excessive publicity?-But it was Dr Smith's own British Medical fournal that gave more space to Illich's Medical Nemesis than to any other book published in the last thirty years and has now, I think, given more to my own Doctors on Trial than to any book since Medical Nemesis. And I wonder if Dr Smith has studied Health Care: The Growing Dilemma,${ }^{1}$ produced by the American firm of McKinsey and Co, the conclusions of which were, firstly, that while expenditure on health has been increasing in all Western countries for many years health has not; and, secondly, that of 22 nations surveyed in 1975 and placed in an order of health status the 21 st (next to last, above only Portugal) was the United States, which spends more absolutely and per caput on health than any other nation, and is the Mecca of all good high-technology doctors. (And, please, don't anyone write and tell me about the falling USA coronary mortality: it is the total picture that counts.)

Finally, pace Dr Smith, Ivan Illich and are not pessimists, unless to find our critics ostrich-like is to be pessimistic. We are realists in the superficial sense: Medical Nemesis contains some 500 references, and Doctors on Trial some 800 - most of them from impeccable medical sources. Not that it is the particular sins of doctors that are of prime interest, but rather their origin in the deeply flawed nature of the Western medical institution, and of the sad Western, high-technology society of which it is a central and integral part. To see and to acknowledge that, and to seek remedy for it for the sake of the young, is to be, I suggest, not a pessimist but a realist in the deepest sense.

JOHN S BRADSHAW

Moycullen,

Co Galway, Ireland

Maxwell, R, Health Care: The Growing Dilemma, 2nd edn. New York, McKinsey and Co Inc, 1975.

\section{Action on alcohol}

SIR,-I was interested to read your leading article (10 February, p 361) on the above subject, and the excellent paper in the same issue ( $\mathrm{p} \mathrm{367)}$ ) by Professor R E Kendell. The implications for the general practitioner are no less than for the psychiatrist. One has seen a very real increase in alcoholism in general practice over the last decade, unfortunately in a much younger age group and among women. Almost always the presentation is because of marital disharmony or financial or family problems, often with already present advanced liver or cerebral damage, or even frank dementia. Earlier diagnosis can be achieved only by educating the dependants to recognise the danger signals, when counselling would be more acceptable and effective.

It is clear that the concept of alcoholism as a disease has produced the public attitude that this is a problem to be handed over to the medical profession. The problem is a byproduct of aftluence, uncontrolled advertising, excessive leisure, and the decline in religion. The public does not want to know, or treats the problem with levity, as occurred recently in a BBC Any Questions programme from Bristol. Many general practitioners have the same attitude-and as a group doctors do not lead by example.

While I do not advocate prohibition or total abstinence, in view of the undoubted social benefits of alcohol, clearly a programme of health education to change public attitudes is overduc. Politicians must face the problem sooner or later-the tax on alcohol and tobacco should be trebled, and serious alcoholrelated offences, such as drunken driving, should be punished by life suspension. Health education should commence with the medical profession itself leading by example, counselling, caring, by asking, "Am I my brother's keeper?"

Cheltenham, (ilos

G H Williamson

SIR,-I found Professor R E Kendell's paper (10) February, p 367) very interesting, but I was surprised that he devoted so little attention to the psychological aspects of this "disease." The following quotation from the Encyclopaedia Britannica on "Drunkenness" is of relevance: "Excessive use of alcoholic liquor appears to be referable to desire on the part of the individual to escape from or ameliorate some unpleasant situation. Persons who are in grave difficulty whether real or imaginary, or who suffer from an inescapable feeling of inadequacy, impotence, frustration, or failure, often turn to alcoholic liquor as an avenue of escape. Leaning more and more on this escape mechanism leads to habitual drunkenness." It is significant that the consumption of drugs used in the treatment of anxiety and depression has also increased dramatically.

Professor Kendell asks whether alcoholism is a medical or a political problem. In the sense that the politicians seem to be doing 